\title{
Article
}

\section{Immigrant Diversity, Institutional Quality, and GVC Position}

\author{
Ying Zhou ${ }^{1}$ and Sajid Anwar ${ }^{2, *(1)}$ \\ 1 School of Management, Jinan University, Guangzhou 510632, China; zoe@stu2017.jnu.edu.cn \\ 2 School of Business and Creative Industries, University of the Sunshine Coast, \\ Sippy Downs, QLD 4556, Australia \\ * Correspondence: sanwar@usc.edu.au
}

check for

updates

Citation: Zhou, Y.; Anwar, S.

Immigrant Diversity, Institutional

Quality, and GVC Position.

Sustainability 2022, 14, 2129. https://

doi.org/10.3390/su14042129

Academic Editor: Bruce Morley

Received: 5 January 2022

Accepted: 11 February 2022

Published: 13 February 2022

Publisher's Note: MDPI stays neutral with regard to jurisdictional claims in published maps and institutional affiliations.

Copyright: (c) 2022 by the authors. Licensee MDPI, Basel, Switzerland. This article is an open access article distributed under the terms and conditions of the Creative Commons Attribution (CC BY) license (https:/ / creativecommons.org/licenses/by/ $4.0 /)$.

\begin{abstract}
This paper investigates the effect of immigrant diversity on a country's position in global value chains (GVCs) and how this effect depends on the institutional quality of destination countries. We investigate this issue using data on 19 manufacturing sectors of 18 OECD countries over the 2000-2014 period. Fixed effects estimation results show that the impact of immigrant diversity on the GVC position is significantly influenced by the institutional quality of destination countries. Specifically, in countries with high (low) institutional quality, immigrant diversity is positively (negatively) associated with the GVC position. Moreover, the interaction effect of immigrant diversity and institutional quality on the GVC position is heterogeneous across immigrant groups and institutional dimensions. This study not only enriches the literature on the relationship between immigrant diversity and GVC position but also discusses new ideas that can promote GVC positions of real economics, which is essential for sustainable economic development.
\end{abstract}

Keywords: diversity of immigrants; global value chain position; institutional quality

\section{Introduction}

With an increase in diversity in the sources of international migration, more attention is being paid to the impact of immigrant diversity on the economic performance of destination countries. For example, immigrant diversity was found to have a positive and statistically significant impact on the productivity of local firms, e.g., [1,2], wages and innovation [3,4], and economic growth [5-8]. This paper aims to investigate the impact of immigrant diversity on the position of destination countries within global value chains (GVCs), which is also important for sustainable economic development.

Owing to a substantial increase in economic interdependence among countries, international trade is increasingly organized within GVCs, where production is sliced into a sequence of value-creating stages, and stages of production are distributed around the globe based on costs or capabilities of different countries. Multinational companies restructure their production and operations through outsourcing and offshoring of intermediates. The formation of GVCs has dramatically changed the competition patterns of international trade. Specifically, trade competition among nations has mostly shifted (i) from final to intermediate products and (ii) to competition in GVC networks [9-12]. Moreover, since the value-added varies considerably across stages of production, a country's position in GVCs is crucial not only for its economic prosperity but also for sustainable economic development [13-16]. Thus, the issue of how to upgrade from low value-added stages of production to high value-added stages has become an important concern of both researchers and policymakers $[17,18]$.

We argue that immigrant diversity affects the GVC position of destination countries through the capability pool effect and social conflict effect. The former effect is positive, while the latter is negative $[19,20]$. Thus, the overall effect of immigrant diversity on the GVC position can be either positive or negative (and may even be zero). As the institutional quality in destination countries is linked to both the capability pool and social conflict 
effects, it is useful to also examine the effect of the institutional quality in host countries on the relationship between immigrant diversity and position within GVCs. The empirical analysis presented in this paper is based on data collected from 18 OECD countries. The dataset covers 19 manufacturing sectors within OECD countries over the 2000-2014 period. The estimation results are highly consistent with our theoretical predictions, and a series of robustness tests confirm the reliability of our main findings.

This paper makes two important contributions to the existing literature. First, by linking the diversity of immigrants with the position of destination countries within GVCs, our work expands existing studies that deal with both the effects of immigrant diversity and the determination of the GVC position. Second, this paper investigates how the institutional quality in destination countries influences the two opposite effects of immigrant diversity, which contribute to the existing literature that aims to explain the contradictory findings on the effects of immigrant diversity in some empirical studies. Furthermore, this paper also contributes to the research that examines the effect of institutions on economic performance.

The remainder of the paper is organized as follows. A theoretical framework is used in Section 2 to develop a testable hypothesis concerning the effect of immigrant diversity on the position of destination countries within GVCs and how this effect depends on the institutional quality of destination countries. Methodology and data are discussed in Section 3. The empirical analysis is presented and discussed in Section 4. A series of robustness testing results are presented in Section 5. Heterogeneity of the interaction effect of immigrant diversity and institutional quality on the GVC position is discussed in Section 6. The last section concludes the paper.

\section{Theoretical Framework and Hypothesis Development}

The GVC framework was originally proposed to explain international production networks driven by large-scale buyers and producers [21]. Over the past two decades, the research framework concerning GVC governance has further expanded, with many studies thoroughly conceptualizing GVC-related upgrading and focusing on different modes and levels of governance operating within GVCs [22-25]. However, important issues concerning the determinants of GVC upgrading remain unresolved, including the effect of immigrant diversity.

Existing studies find that population diversity has both positive and negative effects on local economic performance [26]. The positive impact of immigrant diversity on the GVC position of destination countries comes from the "capability pool effect", which mainly follows from the fact that immigrant diversity is positively associated with production capabilities in destination countries. Individuals with different geographical, ethnic, or cultural backgrounds have unique capabilities to perceive and solve problems [27-31]. Thus, immigrant diversity can bring more heterogeneous capabilities to destination countries.

The capability pool effect of immigrant diversity can promote the GVC position of destination countries for three reasons. First, recent studies on economic complexity have shown that the production of sophisticated goods usually requires higher-level capabilities, and countries with more capabilities can produce more sophisticated goods with high value-added [32]. Since immigrant diversity can increase the number of capabilities of destination counties, countries with a higher level of immigrant diversity must be involved in more sophisticated production stages within GVCs. Second, immigrant diversity can help destination countries to build a more complete labor market where through varying the combination of capabilities utilized to produce goods, local firms can organize the production process more effectively. The production process is highly changeable and customized within GVCs [33]. Therefore, such an increase in flexibility of the labor market due to the diversity of immigrants can help destination countries to gain advantageous positions in GVCs. Finally, existing studies have shown that heterogeneity in workgroups encourages brainstorming activities, which tends to generate new ideas or innovations [34-38]. Thus, by promoting local innovation activities, immigrant diversity can improve the production position of the country within GVCs. 
While the capability pool effect of immigrant diversity on the GVC position of destination countries tends to be positive, the social conflict effect of immigrant diversity on the GVC position of destination countries is likely to be negative. According to the social identity theory, people often categorize themselves into different social categories to build their own social identity. When people perceive themselves as part of a group, they become part of the in-group. Other comparable groups that the individuals do not identify with are called out-group. To sustain social identity, individuals tend to positively evaluate their in-group relative to the out-group and even negatively evaluate the out-group [39]. Inter-group discrimination can cause social conflicts that can have a negative impact on economic performance [40-42]. Accordingly, social identity behaviors (e.g., diversity of languages, beliefs, and culture) involving immigrants can also increase social conflicts [5,20], which can have a negative impact on the GVC position of destination countries. Three explanations can be provided for this. First, social conflicts tend to worsen the local business environment, thereby discouraging foreign companies from investing and setting up subsidiaries in host countries $[43,44]$, which decreases the competitiveness of the relevant host countries in GVCs. Second, social conflicts reduce the positive effect of the increase in the number of immigrants with different skills mentioned earlier, such as the inability to create high value-added products. Third, social conflicts also reduce the productivity of firms, which, in turn, reduces the competitiveness of the firms in GVCs.

As immigrant diversity can have both positive and negative effects on the GVC position of destination countries, it is necessary to explore the factors that determine the relative size of the two opposite effects. Existing studies show that the institutional environment plays a crucial role in national governance $[45,46]$. It can thus be argued that the institutional environment also affects the capability pool and social conflict effect of immigrant diversity. Specifically, a good institutional environment can improve the capability pool effect of immigrant diversity for three reasons. First, since the institutional environment is one of the important factors in the production of GVCs, a good institutional environment can ensure that the varying abilities of immigrants from different origin countries are effectively used in the production of high value-added products. If the institutional environment is poor, there will be problems in the industrial layouts of GVCs of countries, and there is no guarantee that the capability pool effect of immigrant diversity would be effectively utilized. Second, the promotion of the GVC position requires new labor skills, and the matching of labor skills with enterprise needs also depends on the institutional environment. A good institutional environment is characterized by a fair and non-discriminatory labor market, which is open to immigrants and where employment procedures are subject to a high level of transparency. On the other hand, in a poor institutional environment, the labor market is characterized by inefficiencies, including matching efficiency, which decreases the probability of firms hiring suitable workers. This occurs because a good institutional environment decreases frictions in the labor market, which improves efficiency by facilitating a better match between heterogeneous firms and workers. Finally, a good institutional environment is an important condition for ensuring brainstorming and innovative activities. A good institutional environment is conducive to intellectual property protection and where differing views are tolerated. This allows immigrants to share their innovative ideas, which can result in the production of high-value-added products.

A good institutional environment can also decrease social conflicts resulting from immigrant diversity in three ways. First, a good institutional environment effectively protects the basic rights of immigrants, such as the right to vote and property rights. Second, a good institutional environment promotes a fair and discrimination-free employment system. Finally, a good institutional environment promotes a work culture where dissent is tolerated. These factors tend to mitigate social identity behaviors. Thus, the impact of immigrant diversity on the GVC position is affected by the institutional quality of destination countries. (Some existing studies have considered the link between the institutional quality 
and GVC participation (e.g., [47])). Based on the above discussion, we have a hypothesis as follows.

Hypothesis 1: The impact of immigrant diversity on the GVC position is influenced by the institutional quality of destination countries. Specifically, in countries with high (low) institutional quality, immigrant diversity is positively (negatively) associated with the position within GVCs.

\section{Methodology and Data}

To investigate the impact of immigrant diversity on the GVC position of destination countries empirically, following some existing studies $[6,7]$, we used a regression equation, as follows:

$$
G V C P_{i r t}=\beta_{1} B D_{i t}+\beta_{2} \text { Inst }_{i t}+\beta_{3} B D_{i t} * \text { Inst }_{i t}+\beta_{4} X_{i t}+\theta_{i r}+\varphi_{t}+\varepsilon_{i r t}
$$

where $i, r$, and $t$ denote country, sector, and year, respectively. $\theta_{i r}$ is the country-sector fixed effect, $\theta_{t}$ is the time-fixed effect, and $\varepsilon_{i r t}$ is the usual error term.

The dependent variable, GVCP irt is the country-sector GVC position, which is measured by an index. $B D_{i t}$ is immigrant diversity in destination countries, and Inst ${ }_{i t}$ is the institutional quality of destination countries. $B D * I n s t$ is the interaction term. $X$ is a vector of control variables.

\subsection{Variables and Measurements}

\subsubsection{GVC Position Index}

The GVC position of a country affects its coordination and control over the value chain, which in turn determines its ability to capture value. The country-sector GVC position index (More details concerning the GVC position can be found in, among others, [48]. Some existing studies (e.g., [49]) also distinguish between backward and forward GVC participation.) is calculated as follows:

$$
G V C P_{i r t}=\frac{P L v_{-} G V C_{i r t}}{P L y_{-} G V C_{i r t}}
$$

where PLv_GVC $C_{i r t}$ is the average country-sector production forward length (to the end of the chain), which is measured by the ratio of GVC related domestic value-added to its induced gross output. $P L y \_G V C_{i r t}$ is the average country-sector backward production length (to the starting point of the chain), which is measured by the ratio of GVC related foreign value-added to its induced gross output $[48,49]$. The higher the value of the countrysector GVC position index, the more upstream the country-sector is within GVCs. In other words, a higher value of the country-sector GVC position index indicates that the country in question is farther from the end of the chain and closer to the starting point of the chain.

Table 1 shows the average GVC position index for 19 manufacturing sectors of 18 OECD countries in selected years over the 2000-2014 period. As shown in Table 1, except for Canada, the GVC position index values of all countries included in our sample were higher than 0.9, implying that most countries included in our sample were at upstream production stages of GVCs. 
Table 1. The average GVC position index of manufacturing sectors in 18 OECD countries.

\begin{tabular}{ccccc}
\hline Country & $\mathbf{2 0 0 0}$ & $\mathbf{2 0 0 5}$ & $\mathbf{2 0 1 0}$ & $\mathbf{2 0 1 4}$ \\
\hline Australia & 0.9598 & 0.9501 & 1.0226 & 1.0115 \\
Austria & 0.9348 & 0.9267 & 0.9139 & 0.9153 \\
Canada & 0.8627 & 0.8265 & 0.8358 & 0.8222 \\
Denmark & 0.9620 & 0.9501 & 0.9395 & 0.9365 \\
Finland & 0.9984 & 0.9724 & 0.9769 & 0.9616 \\
France & 0.9528 & 0.9422 & 0.9239 & 0.9209 \\
Germany & 0.9404 & 0.9327 & 0.9257 & 0.9182 \\
Greece & 1.0287 & 1.0148 & 1.0007 & 0.9959 \\
Ireland & 0.9882 & 0.9918 & 1.0303 & 1.0187 \\
Luxembourg & 0.9415 & 0.9219 & 0.9289 & 0.9199 \\
Netherlands & 0.9512 & 0.9406 & 0.9503 & 0.9589 \\
Norway & 1.0171 & 1.0213 & 1.0355 & 1.0273 \\
Portugal & 0.9501 & 0.9379 & 0.9163 & 0.9016 \\
Spain & 0.9497 & 0.9351 & 0.9095 & 0.9080 \\
Sweden & 0.9881 & 0.9770 & 0.9759 & 0.9710 \\
Switzerland & 0.9722 & 0.9550 & 0.9508 & 0.9614 \\
United Kingdom & 0.9457 & 0.9346 & 0.9505 & 0.9598 \\
United States & 0.9611 & 0.9341 & 0.9245 & 0.9123 \\
\hline
\end{tabular}

Source: Author calculations based on WIOD Database.

\subsubsection{Immigrant Diversity}

Immigrant attributes, such as language, culture, and ethnicity, are closely associated with their birthplace [6], and hence immigrant diversity is usually measured from a birthplace perspective. We calculated immigrant diversity using the Herfindahl-Hirschman Index as follows.

$$
B D_{i t}=1-\sum_{j=1}^{i} s_{i j t}^{2}
$$

where $S_{i j t}$ is the proportion of immigrants who move from country $j$ to country $i$, in period $t$ and $B D$ ranges from 0 to 1 (a higher value of $B D$ represents a higher level of immigrant diversity).

\subsubsection{Institutional Quality}

The Worldwide Governance Indicators (WGI) available as a part of the World Bank database are widely used to measure the institutional quality at the country level [50]. WGI reflects the traditions and institutions by which authority in a country is exercised. WGI is based on six dimensions: (i) voice and accountability, which measures how can the citizens of a country influence and participate in government decision-making; (ii) political stability and absence of violence, which measures the likelihood that the government of a country may fail or be overthrown; (iii) government effectiveness, which accounts for the quality of public services; (iv) regulatory quality, which accounts for the ability of the government to formulate and implement sound policies and regulations; (v) rule of law, which measures the level of confidence and compliance with law and effectiveness of the judiciary; (vi) corruption control, which measures the extent to which individuals or groups exercise public power for private gain. The score for each dimension varies between -2.5 and 2.5. Based on the six dimensions, we constructed a composite index. The composite index measures the institutional quality of destination countries.

\subsubsection{Control Variables}

Based on related studies, the following control variables were included in Equation (1): (i) the real GDP per capita (PCGDP) as a measure of economic development level of destination countries; (ii) total population $(P O P)$, which is used to capture the market size of destination countries; (iii) proportion of local residents (Local), which measures the size of foreign immigrants in destination countries; (iv) ratio of education expenditure to GDP, 
which aims to measure the level of human capital $(H C)$ in destination countries; (v) ratio of total trade value to GDP (TRADE), which measures the extent of trade openness in destination countries; (vi) ratio of foreign direct investment to GDP (FDI), which measures the extent of foreign direct investment openness in destination countries.

\subsection{Data}

The data used to calculate the GVC position index were sourced from the Global Value Chain Database of the University of International Business and Economics of China (UIBE), which contains the inter-country input and output data for more than 40 countries from 2000 to 2014. Using the United Nations Conference on Trade and Development (UNCTAD), 3-digit classification of SITC Rev.3, a total of 19 manufacturing sectors were identified. (Manufacturing sectors include the production of food, beverage, and tobacco products; Manufacturing of textiles, clothing, and leather goods; Manufacture of wood and cork products (except furniture), straw and woven materials; Paper and paper products manufacturing; Printing and reproduction; Producing coke and refined petroleum products; Chemical products manufacturing; Production of essential drugs and preparations; Rubber, plastic products manufacturing; Manufacture of other non-metallic mineral products; Base metal manufacturing; Manufacturing metal products other than machinery and equipment; Manufacturing of computer, electronic, and optical products; Electrical equipment manufacturing; Mechanical equipment manufacturing; Manufacture of motor vehicles, trailers, and semi-trailers; Other transportation equipment manufacturing; Furniture manufactured, other manufacturing industries; Repair and installation of mechanical equipment). The data used to calculate immigrant diversity were collected from the Institute for Employment Research [51] bilateral migration database. The IAB database includes migration data for 20 OECD countries over the 1980-2010 period with five-year intervals. In our study, immigrants refer to people over the age of 25 who were not born in their adopted country of residence. As the immigrant data involves missing values, we used a smoothing approach to interpolate the missing values. Data on other variables were compiled from the World Bank database [52].

The size of the sample was limited mainly by data availability on immigrants. After collecting data on other variables included in our regression equation, we had a balanced panel, which covered 19 manufacturing sectors in 18 OECD countries over the 2000-2014 period. The descriptive statistics and correlations of the main variables are presented in Table 2. GVCP varied between 0.657 and 1.531 with a mean of 0.958 and a standard deviation of 0.125 , which suggests the presence of significant variation in the GVC position across countries. The $B D$ level varied in the 0.527 to 0.968 range, with a mean of 0.911 and a standard deviation of 0.065 . The estimated correlation coefficient between PCGDP and $T R A D E$, i.e., 0.652 , was relatively high. Still, other correlation coefficients were low, which appears to suggest the absence of significant multicollinearity in our regression model. 
Table 2. Summary statistics.

\begin{tabular}{|c|c|c|c|c|c|c|c|c|c|}
\hline & GVCP & BD & INST & PCGDP & POP & $\mathrm{HC}$ & FDI & TRADE & LOCAL \\
\hline GVCP & 1 & $-0.084^{* * *}$ & $0.030^{* *}$ & $0.107^{* * *}$ & $-0.088^{* * *}$ & $0.057^{* * *}$ & 0.025 * & $0.044^{* * *}$ & $-0.047^{* * *}$ \\
\hline $\mathrm{BD}$ & & 1 & $0.171^{* * *}$ & $0.067^{* * *}$ & $0.096^{* * *}$ & $0.317^{* * *}$ & $-0.268^{* * *}$ & $-0.392^{* * *}$ & $0.062 * * *$ \\
\hline INST & & & 1 & $0.598^{* * *}$ & $-0.220^{* * *}$ & $0.582 * * *$ & $0.208^{* * *}$ & $0.312^{* * *}$ & $-0.170^{* * *}$ \\
\hline PCGDP & & & & 1 & $-0.163^{* * *}$ & $0.396^{* * *}$ & $0.384^{* * *}$ & $0.652^{* * *}$ & $-0.535^{* * *}$ \\
\hline POP & & & & & 1 & $-0.270^{* * *}$ & $-0.185^{* * *}$ & $-0.362^{* * *}$ & $0.125^{* * *}$ \\
\hline $\mathrm{HC}$ & & & & & & 1 & $-0.153^{* * *}$ & $-0.076^{* * *}$ & $0.283^{* * *}$ \\
\hline FDI & & & & & & & 1 & $0.673^{* * *}$ & $-0.304^{* * *}$ \\
\hline TRADE & & & & & & & & 1 & $-0.520^{* * *}$ \\
\hline LOCAL & & & & & & & & & 1 \\
\hline Obs & 5085 & 5130 & 5130 & 5130 & 5130 & 3876 & 5092 & 5130 & 5130 \\
\hline Median & 0.941 & 0.924 & 9.589 & 46.98 & 10.90 & 5.240 & 3.413 & 72.22 & 4.514 \\
\hline Mean & 0.958 & 0.911 & 8.940 & 50.16 & 38.58 & 5.531 & 7.031 & 91.04 & 4.490 \\
\hline SD & 0.125 & 0.065 & 2.029 & 19.61 & 68.66 & 1.156 & 11.59 & 63.30 & 0.0690 \\
\hline Min & 0.657 & 0.527 & 1.446 & 21.26 & 0.436 & 3.230 & 0.00100 & 22.15 & 4.294 \\
\hline Max & 1.531 & 0.968 & 11.82 & 112.0 & 321.5 & 8.560 & 86.59 & 392.8 & 4.588 \\
\hline
\end{tabular}

Note: ${ }^{* * *}, * *$, and ${ }^{*}$ denote significance at the $1 \%, 5 \%$, and $10 \%$, respectively. PCGDP is measured in thousands of US dollars. $P O P$ is measured in millions, and other variables are in percentages.

\section{Empirical Results}

Fixed effects estimation results for Equation (1) are reported in Table 3. Estimation results presented in column 1 of Table 3 showed that the overall effect of immigrant diversity on the GVC position of destination countries was positive and statistically significant. This result continued to hold in column 2 of Table 3, where the institutional quality was introduced as an additional independent variable. The results presented in column 2 also showed that the institutional quality had a positive and statistically significant effect on the GVC position of destination countries. This implies that all else being equal, countries with high institutional quality achieve higher production positions within GVCs. By contrast, countries with low institutional quality tend to lower production positions within GVCs.

In column 3 of Table 3, the regression model was further extended by including the interaction of the institutional quality and immigrant diversity as an additional independent variable. The estimated coefficient of immigrant diversity (i.e., $B D$ ) in column 3 was negative and statistically significant, but the estimated coefficient of the interaction term on the GVC position was positive and statistically significant. This positive impact of the interaction term in column 3 of Table 3 showed that the impact of immigrant diversity on the GVC position depends on the level of the institutional quality of destination countries.

To further investigate the interaction effect of immigrant diversity and the institutional quality on the GVC position of destination countries, we conducted a simple test to obtain the conditional slope of the focal predictor, immigrant diversity. As shown in Figure 1, when the institutional quality was low (i.e., two standard deviations below the mean), immigrant diversity was negatively associated with GVC position. However, when the institutional quality was high (i.e., two standard deviations above the mean), immigrant diversity was positively related to the GVC position. This result re-confirmed our empirical finding that the impact of immigrant diversity on the GVC position varies with the institutional quality of destination countries. Specifically, in countries with higher institutional quality, the capability pool effect of immigrant diversity more than offsets the negative social conflict effect. Hence, immigrant diversity improves the GVC position of destination countries. By contrast, in countries with lower institutional quality, the negative social conflict effect is stronger than the positive capability pool effect. Hence, the overall immigrant diversity effect on the GVC position is negative. This result is highly consistent with the hypothesis presented in Section 2. 
Table 3. Fixed effects estimation of Equation (1).

\begin{tabular}{|c|c|c|c|}
\hline & (1) & (2) & (3) \\
\hline $\mathrm{BD}$ & $\begin{array}{l}0.294^{* * *} \\
(0.0746)\end{array}$ & $\begin{array}{l}0.273^{* * *} \\
(0.0750)\end{array}$ & $\begin{array}{c}-0.508 \text { * } \\
(0.289)\end{array}$ \\
\hline INST & & $\begin{array}{l}0.0109^{* * *} \\
(0.00270)\end{array}$ & $\begin{array}{c}-0.0592 * * \\
(0.0264)\end{array}$ \\
\hline $\mathrm{BD}^{*} \mathrm{INST}$ & & & $\begin{array}{c}0.0772 * * * \\
(0.0293)\end{array}$ \\
\hline PCGDP & $\begin{array}{l}0.00156^{* *} \\
(0.000775)\end{array}$ & $\begin{array}{c}0.000447 \\
(0.000722)\end{array}$ & $\begin{array}{c}0.000728 \\
(0.000733)\end{array}$ \\
\hline POP & $\begin{array}{l}0.00422 * * \\
(0.00183)\end{array}$ & $\begin{array}{c}0.00572 * * * \\
(0.00180)\end{array}$ & $\begin{array}{c}0.00694^{* * *} \\
(0.00188)\end{array}$ \\
\hline $\mathrm{HC}$ & $\begin{array}{c}0.00669 * * \\
(0.00270)\end{array}$ & $\begin{array}{c}0.00537 * * \\
(0.00263)\end{array}$ & $\begin{array}{c}0.00595^{* *} \\
(0.00260)\end{array}$ \\
\hline FDI & $\begin{array}{c}1.78 \times 10^{-5} \\
\left(6.71 \times 10^{-5}\right)\end{array}$ & $\begin{array}{c}3.86 \times 10^{-5} \\
\left(6.50 \times 10^{-5}\right)\end{array}$ & $\begin{array}{c}6.19 \times 10^{-5} \\
\left(6.85 \times 10^{-5}\right)\end{array}$ \\
\hline TRADE & $\begin{array}{c}0.000391 * * \\
(0.000179)\end{array}$ & $\begin{array}{c}0.000438^{* *} \\
(0.000174)\end{array}$ & $\begin{array}{l}0.000440 \text { ** } \\
(0.000172)\end{array}$ \\
\hline LOCAL & $\begin{array}{c}0.489 * * \\
(0.216)\end{array}$ & $\begin{array}{l}0.383 * \\
(0.223)\end{array}$ & $\begin{array}{c}0.340 \\
(0.223)\end{array}$ \\
\hline Constant & $\begin{array}{c}-1.733 \text { * } \\
(1.005)\end{array}$ & $\begin{array}{l}-1.323 \\
(1.029)\end{array}$ & $\begin{array}{l}-0.465 \\
(1.088)\end{array}$ \\
\hline Country FE & YES & YES & YES \\
\hline Industry FE & YES & YES & YES \\
\hline Year FE & YES & YES & YES \\
\hline $\begin{array}{c}\text { Observations } \\
\text { R-squared }\end{array}$ & $\begin{array}{l}3835 \\
0.088\end{array}$ & $\begin{array}{l}3835 \\
0.100\end{array}$ & $\begin{array}{l}3835 \\
0.104\end{array}$ \\
\hline
\end{tabular}

Note: ${ }^{* * *},{ }^{* *}$, and ${ }^{*}$ represent the significance levels of $1 \%, 5 \%$, and $10 \%$, respectively. The values in parentheses below the estimated coefficients are the corresponding robust standard errors. GVCP irt is the dependent variable.

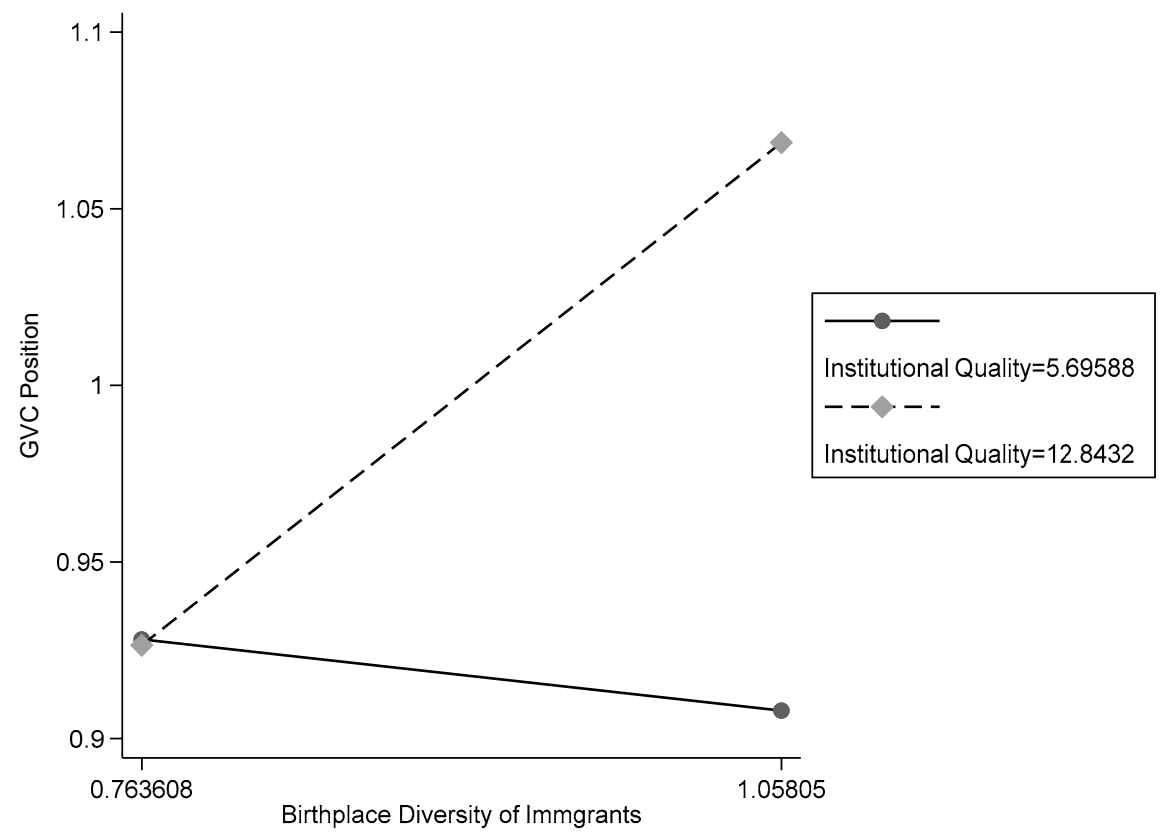

Figure 1. Interaction effect of immigrant diversity and institutional quality.

In Table 4, we used the margins command to calculate the predicted value of the GVC position at each level of the institutional quality, holding immigrant quality at its mean value. As shown in Table 4, when the institutional quality was low, the marginal effect of immigrant diversity on the GVC position was negative, but this effect rose with an increase in the institutional quality. When the institutional quality equaled or exceeded 
7.5, the marginal effects of immigrant diversity on the GVC position became positive. In other words, other things being equal, as the institutional quality increases, the capability pool effect of immigrant diversity on the GVC position continues to increase. At the same time, the social conflict effect of immigrant diversity on GVC position continues to decline. Eventually, the overall effect changes from negative to positive.

Table 4. The marginal effect of immigrant diversity on the GVC position.

\begin{tabular}{|c|c|c|c|c|}
\hline Order & Institutional Quality & Marginal Effect & $\mathbf{z}$ & $p>|\mathbf{z}|$ \\
\hline 1 & -15 & -1.6660 & -2.31 & 0.021 \\
\hline 2 & -13.5 & -1.5502 & -2.28 & 0.022 \\
\hline 3 & -12 & -1.4344 & -2.26 & 0.024 \\
\hline 4 & -10.5 & -1.3187 & -2.23 & 0.026 \\
\hline 5 & -9 & -1.2029 & -2.19 & 0.028 \\
\hline 6 & -7.5 & -1.0871 & -2.15 & 0.031 \\
\hline 7 & -6 & -0.9713 & -2.1 & 0.035 \\
\hline 8 & -4.5 & -0.8555 & -2.05 & 0.041 \\
\hline 9 & -3 & -0.7397 & -1.97 & 0.049 \\
\hline 10 & -1.5 & -0.6239 & -1.88 & 0.060 \\
\hline 11 & 0 & -0.5081 & -1.76 & 0.079 \\
\hline 12 & 1.5 & -0.3923 & -1.59 & 0.113 \\
\hline 13 & 3 & -0.2766 & -1.34 & 0.179 \\
\hline 14 & 4.5 & -0.1608 & -0.97 & 0.331 \\
\hline 15 & 6 & -0.0450 & -0.35 & 0.725 \\
\hline 16 & 7.5 & 0.0708 & 0.75 & 0.456 \\
\hline 17 & 9 & 0.1866 & 2.49 & 0.013 \\
\hline 18 & 10.5 & 0.3024 & 3.88 & 0.000 \\
\hline 19 & 12 & 0.4182 & 4.1 & 0.000 \\
\hline 20 & 13.5 & 0.5340 & 3.92 & 0.000 \\
\hline 21 & 15 & 0.6498 & 3.72 & 0.000 \\
\hline
\end{tabular}

Source: Author calculations.

\section{Robustness Tests}

\subsection{Endogeneity Analysis}

In this section, we investigate the presence of potential endogeneity in regression Equation (1), which arises from reverse causality. For example, an increase in a country's GVC position may increase the demand for workers with heterogeneous capabilities, which will encourage policymakers to attract skilled workers from abroad, thus promoting immigrant diversity. To check this potential endogeneity problem, following related studies [6,53-55], we used a gravity model to predict the proportion of immigrants in a country's population. This allowed us to construct an instrumental variable for immigrant diversity. We used a gravity model as follows:

$$
S_{i j t}=\beta_{0}+\beta_{1} P O P_{1960 i}+\beta_{2} D I S_{i j t}+\beta_{3} B O R D_{i j t}+\beta_{4} O L A N G_{i j t}+\beta_{5} E L A N G_{i j t}+\beta_{6} C O L_{i j t}+\chi_{i t}+\eta_{t}+\epsilon_{t}
$$

where $S_{i j t}$ is the proportion of immigrants from country $j$ to country $i$ in year $t$.

The control variables in Equation (4) include population size of destination country $i$ in $1960\left(P O P_{1960 i}\right)$, bilateral distance between countries $\left(D I S_{i j t}\right)$, whether the country pair has a common border $\left(B O R D_{i j t}\right)$, whether a country pair has a common official language $\left(O L A N G_{i j t}\right)$, whether a country pair has a common minority language $\left(E L A N G_{i j t}\right)$, whether a country pair has a common colonial history $\left(C O L_{i j t}\right) . \eta_{t}$ and $\chi_{i t}$, respectively, are year and country-year dummies, and $\epsilon_{t}$ is the usual error term. (The data on these variables were collected from the CEPII database.)

By substituting the predicted proportion of immigrants in Equation (3), we obtained an instrumental variable for immigrant diversity. The instrumental variable was used in a two-stage least squares (2SLS) estimation of Equation (1). 2SLS estimation results presented in Table 5 are qualitatively similar to those presented in Table 3 . In column 3 of Table 5, the effect of immigrant diversity on the GVC position remained negative and statistically 
significant, and the estimated interaction effect was positive, implying that our findings are not influenced by a potential endogeneity problem. Moreover, all of the Kleibergen-PAAP $F$ values reported in Table 5 were greater than 10, thus rejecting the null hypothesis of weak instruments.

Table 5. 2SLS estimation of Equation (1).

\begin{tabular}{|c|c|c|c|}
\hline & (1) & (2) & (3) \\
\hline \multirow[t]{2}{*}{$\mathrm{BD}$} & $0.499^{* * *}$ & $0.367^{* * *}$ & -0.665 \\
\hline & $(0.0869)$ & $(0.134)$ & $(0.432)$ \\
\hline \multirow[t]{2}{*}{ INST } & & $0.0205^{* * *}$ & $-0.0961^{* *}$ \\
\hline & & $(0.00284)$ & $(0.0410)$ \\
\hline \multirow[t]{2}{*}{$\mathrm{BD}^{*} \mathrm{INST}$} & & & $0.128^{* * *}$ \\
\hline & & & $(0.0451)$ \\
\hline \multirow[t]{2}{*}{ PCGDP } & $0.000995^{* *}$ & -0.000496 & -0.000247 \\
\hline & $(0.000462)$ & $(0.000517)$ & $(0.000527)$ \\
\hline \multirow[t]{2}{*}{ POP } & $0.00488^{* * *}$ & $0.00610^{* * *}$ & $0.00835^{* * *}$ \\
\hline & $(0.000836)$ & $(0.000853)$ & $(0.00111)$ \\
\hline \multirow[t]{2}{*}{$\mathrm{HC}$} & $0.00374 *$ & 0.00253 & 0.000839 \\
\hline & $(0.00207)$ & $(0.00206)$ & $(0.00205)$ \\
\hline \multirow[t]{2}{*}{ FDI } & $1.95 \times 10^{-5}$ & $-3.80 \times 10^{-5}$ & $-1.83 \times 10^{-5}$ \\
\hline & $\left(7.72 \times 10^{-5}\right)$ & $\left(7.51 \times 10^{-5}\right)$ & $\left(7.57 \times 10^{-5}\right)$ \\
\hline \multirow[t]{2}{*}{ TRADE } & $0.000324^{* * *}$ & $0.000469^{* * *}$ & $0.000365^{* * *}$ \\
\hline & $\left(9.46 \times 10^{-5}\right)$ & $(0.000106)$ & $(0.000105)$ \\
\hline \multirow[t]{2}{*}{ LOCAL } & $0.670 * * *$ & 0.137 & 0.181 \\
\hline & $(0.127)$ & $(0.139)$ & $(0.137)$ \\
\hline Kleibergen-Paap F & 240.925 & 689.451 & 232.427 \\
\hline Country FE & YES & YES & YES \\
\hline Industry FE & YES & YES & YES \\
\hline Year FE & YES & YES & YES \\
\hline Observations & 3835 & 3571 & 3571 \\
\hline R-squared & 0.082 & 0.093 & 0.098 \\
\hline
\end{tabular}
underneath the estimated coefficients are the corresponding robust standard errors.

\subsection{Sample Self-Selection Bias}

Because of the immigration policy orientation of destination countries, immigrants in our sample may be subject to self-selection bias. To control for possible self-selection bias in immigrant diversity, we used the migration willingness index proposed by the Gallup market research report. (The Gallup migration willingness index is based on a survey of nearly 348,000 adults from 148 countries between 2007 and 2010). The Gallup migration willingness index reflects the willingness of people to move into or out of a country so that it can capture the information on the potential net migration of each country without restrictions on migration [56]. We first regressed immigrant diversity on the Gallup migration willingness index and recorded the estimated residuals. The estimated residuals can be interpreted as the degree of immigration restrictions in destination countries. As the degree of immigration restrictions in a country may change over time, to better control the self-selection effect of immigrants, we included the interaction of the estimated residuals and year dummies in Equation (1). Fixed effects estimation results pertaining to the extended version of Equation (1) are presented in Table 6, where the estimated coefficient of the interaction of immigrant diversity and institutional quality remained positive and statistically significant, but the separate effect of immigrant diversity and institutional quality on the GVC position was statistically insignificant in column (3). Thus, our main result concerning the moderating effect of the institutional quality on the relationship between immigrant diversity and GVC position of destination countries was robust to the self-section bias. 
Table 6. Re-estimation of Equation (1) after accounting for self-selection bias in our sample.

\begin{tabular}{|c|c|c|c|}
\hline & (1) & (2) & (3) \\
\hline \multirow[t]{2}{*}{$\mathrm{BD}$} & $0.287^{* * *}$ & $0.275^{* * *}$ & -0.311 \\
\hline & $(0.0767)$ & $(0.0762)$ & $(0.292)$ \\
\hline \multirow[t]{2}{*}{ INST } & & $0.0103^{* * *}$ & -0.0427 \\
\hline & & $(0.00288)$ & $(0.0264)$ \\
\hline \multirow[t]{2}{*}{$\mathrm{BD} * \mathrm{INST}$} & & & $0.0584^{* *}$ \\
\hline & & & $(0.0293)$ \\
\hline \multirow[t]{2}{*}{ PCGDP } & $0.00138^{*}$ & 0.000486 & 0.000743 \\
\hline & $(0.000758)$ & (0.000686) & $(0.000689)$ \\
\hline \multirow[t]{2}{*}{ POP } & 0.00338 & $0.00520 * *$ & $0.00637^{* * *}$ \\
\hline & $(0.00209)$ & $(0.00213)$ & $(0.00221)$ \\
\hline \multirow[t]{2}{*}{$\mathrm{HC}$} & $0.00706^{* * *}$ & $0.00564 * *$ & $0.00588^{* *}$ \\
\hline & $(0.00271)$ & $(0.00263)$ & $(0.00263)$ \\
\hline \multirow[t]{2}{*}{ FDI } & $-5.19 \times 10^{-5}$ & $-2.37 \times 10^{-5}$ & $2.64 \times 10^{-6}$ \\
\hline & $\left(6.46 \times 10^{-5}\right)$ & $\left(6.25 \times 10^{-5}\right)$ & $\left(6.70 \times 10^{-5}\right)$ \\
\hline \multirow[t]{2}{*}{ TRADE } & $0.000366^{* *}$ & $0.000425^{* *}$ & $0.000430 * *$ \\
\hline & $(0.000185)$ & $(0.000182)$ & $(0.000180)$ \\
\hline \multirow[t]{2}{*}{ LOCAL } & $0.454^{* *}$ & 0.367 & 0.346 \\
\hline & $(0.219)$ & $(0.224)$ & $(0.225)$ \\
\hline \multirow[t]{2}{*}{ Constant } & -1.544 & -1.238 & -0.650 \\
\hline & $(1.025)$ & $(1.037)$ & $(1.116)$ \\
\hline Residuals * Year & YES & YES & YES \\
\hline Country FE & YES & YES & YES \\
\hline Industry FE & YES & YES & YES \\
\hline Year FE & YES & YES & YES \\
\hline Observations & 3835 & 3835 & 3835 \\
\hline R-squared & 0.098 & 0.109 & 0.111 \\
\hline
\end{tabular}

Note: ${ }^{* * *},{ }^{* *}$, and ${ }^{*}$ represent the significance levels of $1 \%, 5 \%$, and $10 \%$, respectively. Values in parentheses underneath the estimated coefficients are the corresponding robust standard errors.

\subsection{Alternative GVC Position Index}

In the benchmark regressions shown in Table 3, we calculated a country's position within GVCs using the method developed by Wang, Wei, Yu, and Zhu [48]. For a robustness check, we used an alternative measure of the GVC position proposed by Koopman, Wang, and Wei [57]. The estimation results using the alternative GVC position index are shown in Table 7, where the estimated effect of immigrant diversity on the GVC position was significantly related to the level of the institutional quality, and the overall effect of immigrant diversity on the GVC position was positive. This implies that our main findings were not influenced by the method used to measure the GVC positions of destination countries. 
Table 7. Robustness test: Alternative GVC position index.

\begin{tabular}{|c|c|c|c|}
\hline & (1) & (2) & (3) \\
\hline $\mathrm{BD}$ & $\begin{array}{c}1.058^{* * *} \\
(0.112)\end{array}$ & $\begin{array}{c}1.035 * * * \\
(0.111)\end{array}$ & $\begin{array}{c}-1.315^{* * *} \\
(0.282)\end{array}$ \\
\hline INST & & $\begin{array}{c}0.00199 \\
(0.00121)\end{array}$ & $\begin{array}{c}-0.171^{* * *} \\
(0.0193)\end{array}$ \\
\hline $\mathrm{BD} * \mathrm{INST}$ & & & $\begin{array}{l}0.188^{* * *} \\
(0.0210)\end{array}$ \\
\hline PCGDP & $\begin{array}{c}0.000336 \\
(0.000294)\end{array}$ & $\begin{array}{c}0.000244 \\
(0.000298)\end{array}$ & $\begin{array}{c}0.000936^{* * *} \\
(0.000283)\end{array}$ \\
\hline POP & $\begin{array}{c}-0.00148 \\
(0.000944)\end{array}$ & $\begin{array}{c}-0.00142 \\
(0.000925)\end{array}$ & $\begin{array}{l}-0.000348 \\
(0.000856)\end{array}$ \\
\hline $\mathrm{HC}$ & $\begin{array}{l}0.00249 \text { ** } \\
(0.000991)\end{array}$ & $\begin{array}{l}0.00221 * * \\
(0.00104)\end{array}$ & $\begin{array}{l}-0.000715 \\
(0.000963)\end{array}$ \\
\hline FDI & $\begin{array}{c}0.000103^{* * *} \\
\left(2.93 \times 10^{-5}\right)\end{array}$ & $\begin{array}{c}0.000109^{* * *} \\
\left(2.82 \times 10^{-5}\right)\end{array}$ & $\begin{array}{c}0.000119^{* * *} \\
\left(2.40 \times 10^{-5}\right)\end{array}$ \\
\hline TRADE & $\begin{array}{l}-0.000872^{* * *} \\
\left(9.36 \times 10^{-5}\right)\end{array}$ & $\begin{array}{l}-0.000849^{* * *} \\
\left(9.39 \times 10^{-5}\right)\end{array}$ & $\begin{array}{l}-0.000961^{* * *} \\
\left(9.17 \times 10^{-5}\right)\end{array}$ \\
\hline LOCAL & $\begin{array}{l}-0.0311 \\
(0.0987)\end{array}$ & $\begin{array}{l}-0.0596 \\
(0.0951)\end{array}$ & $\begin{array}{l}-0.0580 \\
(0.0968)\end{array}$ \\
\hline Constant & $\begin{array}{l}-0.864 * \\
(0.462)\end{array}$ & $\begin{array}{l}-0.730 \\
(0.446)\end{array}$ & $\begin{array}{c}1.383^{* * *} \\
(0.507)\end{array}$ \\
\hline Country FE & YES & YES & YES \\
\hline Industry FE & YES & YES & YES \\
\hline Year FE & YES & YES & YES \\
\hline $\begin{array}{l}\text { Observations } \\
\text { R-squared }\end{array}$ & $\begin{array}{l}2641 \\
0.306\end{array}$ & $\begin{array}{l}2641 \\
0.307\end{array}$ & $\begin{array}{l}2641 \\
0.355\end{array}$ \\
\hline
\end{tabular}

Note: ${ }^{* * *},{ }^{* *}$, and ${ }^{*}$ represent the significance levels of $1 \%, 5 \%$, and $10 \%$, respectively. The values in parentheses below the estimated coefficients are the corresponding robust standard errors.

\subsection{Alternative Immigrant Diversity Index}

The impact of immigrant diversity on the GVC position may vary across the education levels of immigrant groups. To investigate this issue, immigrants were divided into three groups: high-skilled, medium-skilled, and low-skilled. The grouping was based on whether immigrants had completed a college or high school education. Specifically, the high-skilled group refers to the immigrants with a college education; the medium-skilled group refers to the immigrants with high school education, and low-skilled immigrants who had not completed high school education. Fixed effect estimation results across education levels of immigrant groups are shown in Table 8, where columns 1-2, 3-4, and 5-6, respectively, correspond to high-skilled, medium-skilled, and low-skilled immigrant groups. The estimated coefficient of immigrant diversity $(B D)$ was positive at the $1 \%$ level of significance in columns 1,3, and 5, implying that the overall effect of immigrant diversity on the GVC position is positive and statistically significant across education levels of immigrant groups. The estimated coefficient of the interaction of immigrant diversity and institutional quality was positive and statistically significant in columns 2, 4, and 6 . This implies that our main findings were not influenced by the method used to measure immigrant diversity. 
Table 8. Robustness test: Alternative immigrant diversity index.

\begin{tabular}{|c|c|c|c|c|c|c|}
\hline & (1) & (2) & (3) & (4) & (5) & (6) \\
\hline $\mathrm{BD}$ & $\begin{array}{l}0.402^{* * *} \\
(0.0799)\end{array}$ & $\begin{array}{l}-0.176 \\
(0.293)\end{array}$ & $\begin{array}{l}0.228^{* * *} \\
(0.0476)\end{array}$ & $\begin{array}{l}-0.285 \\
(0.237)\end{array}$ & $\begin{array}{l}0.189^{* * *} \\
(0.0461)\end{array}$ & $\begin{array}{c}-0.445^{* *} \\
(0.196)\end{array}$ \\
\hline INST & $\begin{array}{c}0.00888^{* * * *} \\
(0.00273)\end{array}$ & $\begin{array}{l}-0.0466 \\
(0.0283)\end{array}$ & $\begin{array}{c}0.00948^{* * * *} \\
(0.00273)\end{array}$ & $\begin{array}{c}-0.0395 \text { * } \\
(0.0223)\end{array}$ & $\begin{array}{l}0.0103^{* * *} \\
(0.00273)\end{array}$ & $\begin{array}{c}-0.0493^{* * *} \\
(0.0183)\end{array}$ \\
\hline $\mathrm{BD} * \mathrm{INST}$ & & $\begin{array}{l}0.0606^{*} \\
(0.0311)\end{array}$ & & $\begin{array}{c}0.0539 * * \\
(0.0251)\end{array}$ & & $\begin{array}{c}0.0665^{* * *} \\
(0.0209)\end{array}$ \\
\hline PCGDP & $\begin{array}{c}0.000600 \\
(0.000718)\end{array}$ & $\begin{array}{c}0.000709 \\
(0.000721)\end{array}$ & $\begin{array}{c}0.000556 \\
(0.000714)\end{array}$ & $\begin{array}{c}0.000532 \\
(0.000715)\end{array}$ & $\begin{array}{c}0.000648 \\
(0.000707)\end{array}$ & $\begin{array}{c}0.000539 \\
(0.000707)\end{array}$ \\
\hline POP & $\begin{array}{c}0.00618^{* * *} \\
(0.00180)\end{array}$ & $\begin{array}{c}0.00722^{* * *} \\
(0.00186)\end{array}$ & $\begin{array}{c}0.00571^{* * *} \\
(0.00177)\end{array}$ & $\begin{array}{c}0.00677^{* * *} \\
(0.00182)\end{array}$ & $\begin{array}{c}0.00565^{* * *} \\
(0.00178)\end{array}$ & $\begin{array}{c}0.00727^{* * *} \\
(0.00190)\end{array}$ \\
\hline $\mathrm{HC}$ & $\begin{array}{c}0.00272 \\
(0.00262)\end{array}$ & $\begin{array}{c}0.00292 \\
(0.00262)\end{array}$ & $\begin{array}{c}0.00338 \\
(0.00266)\end{array}$ & $\begin{array}{c}0.00350 \\
(0.00266)\end{array}$ & $\begin{array}{c}0.00432 \\
(0.00262)\end{array}$ & $\begin{array}{c}0.00369 \\
(0.00265)\end{array}$ \\
\hline FDI & $\begin{array}{l}-4.28 \times 10^{-6} \\
\left(6.21 \times 10^{-5}\right)\end{array}$ & $\begin{array}{c}9.45 \times 10^{-6} \\
\left(6.31 \times 10^{-5}\right)\end{array}$ & $\begin{array}{l}-2.97 \times 10^{-6} \\
\left(6.11 \times 10^{-5}\right)\end{array}$ & $\begin{array}{c}1.69 \times 10^{-5} \\
\left(6.29 \times 10^{-5}\right)\end{array}$ & $\begin{array}{c}6.66 \times 10^{-6} \\
\left(6.29 \times 10^{-5}\right)\end{array}$ & $\begin{array}{c}3.51 \times 10^{-5} \\
\left(6.53 \times 10^{-5}\right)\end{array}$ \\
\hline TRADE & $\begin{array}{l}0.000292 * \\
(0.000168)\end{array}$ & $\begin{array}{l}0.000313 * \\
(0.000167)\end{array}$ & $\begin{array}{l}0.000300 * \\
(0.000171)\end{array}$ & $\begin{array}{l}0.000320 * \\
(0.000169)\end{array}$ & $\begin{array}{l}0.000314 * \\
(0.000168)\end{array}$ & $\begin{array}{l}0.000312 * \\
(0.000165)\end{array}$ \\
\hline LOCAL & $\begin{array}{c}0.592^{* * *} \\
(0.216)\end{array}$ & $\begin{array}{c}0.557^{* *} \\
(0.218)\end{array}$ & $\begin{array}{c}0.542^{* *} \\
(0.220)\end{array}$ & $\begin{array}{c}0.498^{* *} \\
(0.223)\end{array}$ & $\begin{array}{l}0.541 * * \\
(0.231)\end{array}$ & $\begin{array}{c}0.462 * * \\
(0.234)\end{array}$ \\
\hline Constant & $\begin{array}{c}-2.359 * * \\
(0.999)\end{array}$ & $\begin{array}{l}-1.704 \\
(1.086)\end{array}$ & $\begin{array}{c}-1.967 * \\
(1.006)\end{array}$ & $\begin{array}{l}-1.328 \\
(1.095)\end{array}$ & $\begin{array}{c}-1.939 * \\
(1.060)\end{array}$ & $\begin{array}{l}-1.044 \\
(1.130)\end{array}$ \\
\hline Country FE & YES & YES & YES & YES & YES & YES \\
\hline Industry FE & YES & YES & YES & YES & YES & YES \\
\hline Year FE & YES & YES & YES & YES & YES & YES \\
\hline Observations & 3835 & 3835 & 3835 & 3835 & 3835 & 3835 \\
\hline R-squared & 0.110 & 0.112 & 0.112 & 0.114 & 0.105 & 0.111 \\
\hline
\end{tabular}

Note: ${ }^{* * *},{ }^{* *}$, and ${ }^{*}$ represent the significance levels of $1 \%, 5 \%$, and $10 \%$, respectively. The values in parentheses below the estimated coefficients are the corresponding robust standard errors.

\subsection{Poisson Pseudo Maximum Likelihood Estimation}

The benchmark regression results presented in Table 3 were based on FE estimation. Several empirical studies on international trade use the Poisson pseudo maximum likelihood (PPML) estimation technique to solve the problem of zero values in international trade flows. Because sector-level data on GVC positions include some zeros, Equation (1) was re-estimated using the PPML technique. The PPML estimation results are shown in Table 8. The estimated results presented in Table 9 were qualitatively similar to FE estimation results presented in Table 3. Therefore, it can be argued that our FE estimation results were robust to the choice of the estimation technique. 
Table 9. Poisson pseudo maximum likelihood (PPML) estimation of Equation (1).

\begin{tabular}{|c|c|c|c|}
\hline & (1) & (2) & (3) \\
\hline $\mathrm{BD}$ & $\begin{array}{l}0.300^{* * *} \\
(0.0624)\end{array}$ & $\begin{array}{l}0.279 * * * \\
(0.0607)\end{array}$ & $\begin{array}{c}-0.519 * * \\
(0.226)\end{array}$ \\
\hline INST & & $\begin{array}{l}0.0116^{* * *} \\
(0.00154)\end{array}$ & $\begin{array}{c}-0.0599 * * * \\
(0.0198)\end{array}$ \\
\hline $\mathrm{BD}^{*} \mathrm{INST}$ & & & $\begin{array}{c}0.0788^{* * * *} \\
(0.0217)\end{array}$ \\
\hline PCGDP & $\begin{array}{l}0.00167 * * * \\
(0.000427)\end{array}$ & $\begin{array}{c}0.000492 \\
(0.000433)\end{array}$ & $\begin{array}{l}0.000777 \text { * } \\
(0.000441)\end{array}$ \\
\hline POP & $\begin{array}{l}0.00422 * * * \\
(0.000795)\end{array}$ & $\begin{array}{l}0.00586^{* * *} \\
(0.000815)\end{array}$ & $\begin{array}{l}0.00711^{* * *} \\
(0.000908)\end{array}$ \\
\hline $\mathrm{HC}$ & $\begin{array}{c}0.00713^{* * *} \\
(0.00193)\end{array}$ & $\begin{array}{c}0.00571^{* * *} \\
(0.00191)\end{array}$ & $\begin{array}{c}0.00629 * * * \\
(0.00191)\end{array}$ \\
\hline FDI & $\begin{array}{c}1.53 \times 10^{-5} \\
\left(7.80 \times 10^{-5}\right)\end{array}$ & $\begin{array}{c}3.70 \times 10^{-5} \\
\left(7.71 \times 10^{-5}\right)\end{array}$ & $\begin{array}{c}6.20 \times 10^{-5} \\
\left(7.74 \times 10^{-5}\right)\end{array}$ \\
\hline TRADE & $\begin{array}{c}0.000401^{* * *} \\
\left(9.13 \times 10^{-5}\right)\end{array}$ & $\begin{array}{c}0.000453^{* * *} \\
\left(9.09 \times 10^{-5}\right)\end{array}$ & $\begin{array}{c}0.000454^{* * *} \\
\left(9.08 \times 10^{-5}\right)\end{array}$ \\
\hline LOCAL & $\begin{array}{c}0.504 * * * \\
(0.111)\end{array}$ & $\begin{array}{c}0.394 * * * \\
(0.113)\end{array}$ & $\begin{array}{c}0.351 * * * \\
(0.113)\end{array}$ \\
\hline Constant & $\begin{array}{c}-2.828^{* * *} \\
(0.511)\end{array}$ & $\begin{array}{c}-2.396^{* * *} \\
(0.518)\end{array}$ & $\begin{array}{c}-1.523^{* * *} \\
(0.571)\end{array}$ \\
\hline Country FE & YES & YES & YES \\
\hline Industry FE & YES & YES & YES \\
\hline Year FE & YES & YES & YES \\
\hline $\begin{array}{c}\text { Observations } \\
\text { R-squared }\end{array}$ & $\begin{array}{c}3835 \\
0.0076\end{array}$ & $\begin{array}{c}3835 \\
0.0076\end{array}$ & $\begin{array}{c}3835 \\
0.0076\end{array}$ \\
\hline
\end{tabular}

Note: ${ }^{* * *}, * *$, and ${ }^{*}$ show significance at the $1 \%, 5 \%$, and $10 \%$ levels, respectively. Values in parentheses underneath the estimated coefficients are the corresponding robust standard errors.

\subsection{Removing Outliers}

It is well-known that outliers in a sample can have a significant effect on estimation results. To investigate whether our findings were affected by the presence of outliers in our sample, we used two approaches: (a) all dependent variable observations with residuals greater than two standard deviations (SD) were excluded from the sample; and (b) the dependent variable observations were winsorized at $1 \%$ and $99 \%$ levels. Fixed effects estimation results based on the first approach are shown in columns 1-3 of Table 10, columns 4-6 show the estimation results based on the second approach. Estimation results based on both approaches were qualitatively similar to those presented in Table 3. Thus, it can be argued that our benchmark results were not affected by the presence of outliers in the sample. 
Table 10. Fixed effects estimation of Equation (1) after removing outliers.

\begin{tabular}{|c|c|c|c|c|c|c|}
\hline & (1) & (2) & (3) & (4) & (5) & (6) \\
\hline $\mathrm{BD}$ & $\begin{array}{l}0.278^{* * *} \\
(0.0738)\end{array}$ & $\begin{array}{l}0.257^{* * *} \\
(0.0739)\end{array}$ & $\begin{array}{c}-0.637 * * \\
(0.267)\end{array}$ & $\begin{array}{l}0.288^{* * *} \\
(0.0437)\end{array}$ & $\begin{array}{l}0.266^{* * *} \\
(0.0435)\end{array}$ & $\begin{array}{c}-0.572 * * * \\
(0.205)\end{array}$ \\
\hline INST & & $\begin{array}{l}0.0115^{* * *} \\
(0.00248)\end{array}$ & $\begin{array}{c}-0.0686^{* * *} \\
(0.0242)\end{array}$ & & $\begin{array}{l}0.0114^{* * *} \\
(0.00153)\end{array}$ & $\begin{array}{c}-0.0637^{* * *} \\
(0.0180)\end{array}$ \\
\hline $\mathrm{BD} * \mathrm{INST}$ & & & $\begin{array}{c}0.0883^{* * *} \\
(0.0270)\end{array}$ & & & $\begin{array}{c}0.0828^{* * * *} \\
(0.0198)\end{array}$ \\
\hline PCGDP & $\begin{array}{l}0.00142^{* *} \\
(0.000719)\end{array}$ & $\begin{array}{c}0.000238 \\
(0.000689)\end{array}$ & $\begin{array}{c}0.000570 \\
(0.000714)\end{array}$ & $\begin{array}{l}0.00140^{* * * *} \\
(0.000434)\end{array}$ & $\begin{array}{c}0.000235 \\
(0.000459)\end{array}$ & $\begin{array}{c}0.000533 \\
(0.000463)\end{array}$ \\
\hline POP & $\begin{array}{l}0.00338 * \\
(0.00183)\end{array}$ & $\begin{array}{c}0.00494^{* * *} \\
(0.00179)\end{array}$ & $\begin{array}{c}0.00633^{* * *} \\
(0.00190)\end{array}$ & $\begin{array}{l}0.00363^{* * *} \\
(0.000729)\end{array}$ & $\begin{array}{l}0.00519 * * * \\
(0.000753)\end{array}$ & $\begin{array}{l}0.00649 * * * \\
(0.000813)\end{array}$ \\
\hline $\mathrm{HC}$ & $\begin{array}{c}0.00574^{* *} \\
(0.00262)\end{array}$ & $\begin{array}{l}0.00430 * \\
(0.00256)\end{array}$ & $\begin{array}{l}0.00498 * \\
(0.00254)\end{array}$ & $\begin{array}{c}0.00587^{* * *} \\
(0.00171)\end{array}$ & $\begin{array}{c}0.00451^{* * *} \\
(0.00171)\end{array}$ & $\begin{array}{c}0.00514^{* * *} \\
(0.00171)\end{array}$ \\
\hline FDI & $\begin{array}{c}2.23 \times 10^{-5} \\
\left(7.82 \times 10^{-5}\right)\end{array}$ & $\begin{array}{c}4.29 \times 10^{-5} \\
\left(7.62 \times 10^{-5}\right)\end{array}$ & $\begin{array}{c}6.99 \times 10^{-5} \\
\left(7.93 \times 10^{-5}\right)\end{array}$ & $\begin{array}{c}1.06 \times 10^{-5} \\
\left(7.62 \times 10^{-5}\right)\end{array}$ & $\begin{array}{c}3.28 \times 10^{-5} \\
\left(7.56 \times 10^{-5}\right)\end{array}$ & $\begin{array}{c}5.83 \times 10^{-5} \\
\left(7.57 \times 10^{-5}\right)\end{array}$ \\
\hline TRADE & $\begin{array}{c}0.000345^{* *} \\
(0.000169)\end{array}$ & $\begin{array}{c}0.000394^{* *} \\
(0.000164)\end{array}$ & $\begin{array}{c}0.000395^{* *} \\
(0.000162)\end{array}$ & $\begin{array}{c}0.000353^{* * *} \\
\left(7.80 \times 10^{-5}\right)\end{array}$ & $\begin{array}{c}0.000399^{* * *} \\
\left(7.76 \times 10^{-5}\right)\end{array}$ & $\begin{array}{c}0.000400^{* * *} \\
\left(7.75 \times 10^{-5}\right)\end{array}$ \\
\hline LOCAL & $\begin{array}{l}0.481^{* *} \\
(0.216)\end{array}$ & $\begin{array}{l}0.371 \text { * } \\
(0.222)\end{array}$ & $\begin{array}{c}0.322 \\
(0.221)\end{array}$ & $\begin{array}{c}0.514 * * * \\
(0.101)\end{array}$ & $\begin{array}{l}0.402^{* * *} \\
(0.101)\end{array}$ & $\begin{array}{c}0.356^{* * *} \\
(0.101)\end{array}$ \\
\hline Constant & $\begin{array}{c}-1.669 * \\
(1.011)\end{array}$ & $\begin{array}{l}-1.241 \\
(1.028)\end{array}$ & $\begin{array}{l}-0.263 \\
(1.079)\end{array}$ & $\begin{array}{c}-1.820 * * * \\
(0.463)\end{array}$ & $\begin{array}{c}-1.381 * * * \\
(0.463)\end{array}$ & $\begin{array}{l}-0.463 \\
(0.511)\end{array}$ \\
\hline Country FE & YES & YES & YES & YES & YES & YES \\
\hline Industry FE & YES & YES & YES & YES & YES & YES \\
\hline Year FE & YES & YES & YES & YES & YES & YES \\
\hline Observations & 3658 & 3658 & 3658 & 3758 & 3758 & 3758 \\
\hline R-squared & 0.083 & 0.099 & 0.105 & 0.081 & 0.096 & 0.101 \\
\hline
\end{tabular}

Note: $* * * * *$, and ${ }^{*}$ represent significance at the $1 \%, 5 \%$, and $10 \%$ level, respectively. The values in parentheses underneath the estimated coefficients are the corresponding robust standard errors. The results presented in columns 1-3 were based on the sample where all dependent variable values greater than two standard deviations (SD) were excluded from the sample. The results presented in columns 4-6 were based on the sample where the dependent variable observations were winsorized at $1 \%$ and $99 \%$ levels.

\section{Further Analysis}

The institutional quality index used in this paper included six dimensions. Since each institutional dimension may play a different role in national governance, we further investigated whether the impact of the institutional quality on the relationship between immigrant diversity and GVC position varied significantly across institutional dimensions. (Using data on 63 countries over the 2005-2015 period, Barbero and Rodriguez-Crespo examined the effect of the institutional quality on GVC participation. They also distinguished between forward and backward involvement). Fixed effects estimation results are shown in Table 11, where columns 1 to 6 correspond to Control of Corruption (CC), Government Effectiveness (GE), Political Stability and Absence of Violence (PV), Rule of Law (RL), Regulatory Quality (RQ), and Voice and Accountability (VA), respectively. In Table 11, the estimated coefficient of the interaction of immigrant diversity and institutional quality was positive and statistically significant for only three institutional dimensions (GE, PV, and $\mathrm{RQ})$. This result implies that the GE, $P V$, and RQ dimensions of the institutional quality play a relatively more important role in the relationship between immigrant diversity and the GVC position of destination countries. Specifically, immigrant diversity is more likely to have a positive effect on the GVC position in destination countries with high government efficiency, political stability, and regulatory quality. By contrast, immigrant diversity is more likely to have a negative effect on the GVC position in destination countries with low government efficiency, political stability, and regulatory quality. 
Table 11. Heterogeneous impact of immigrant diversity across institutional dimensions.

\begin{tabular}{|c|c|c|c|c|c|c|}
\hline & (1) & (2) & (3) & (4) & (5) & (6) \\
\hline & $\mathrm{CC}$ & GE & PV & RL & RQ & VA \\
\hline \multirow[t]{2}{*}{$\mathrm{BD}$} & 0.186 & -0.255 & -0.209 & 0.421 & -0.0613 & 0.231 \\
\hline & $(0.122)$ & $(0.190)$ & $(0.228)$ & $(0.256)$ & $(0.184)$ & $(0.221)$ \\
\hline \multirow[t]{2}{*}{ INS } & -0.0223 & $-0.260 * * *$ & $-0.204^{* *}$ & 0.170 & $-0.137^{*}$ & -0.0202 \\
\hline & $(0.0733)$ & $(0.0997)$ & $(0.0976)$ & $(0.157)$ & (0.0739) & $(0.136)$ \\
\hline \multirow[t]{2}{*}{$\mathrm{BD} * \mathrm{INS}$} & 0.0456 & $0.297^{* * *}$ & $0.226^{* *}$ & -0.128 & $0.188^{* *}$ & 0.0458 \\
\hline & $(0.0813)$ & $(0.107)$ & (0.103) & $(0.173)$ & $(0.0839)$ & $(0.154)$ \\
\hline \multirow[t]{2}{*}{ PCGDP } & 0.00134 * & $0.00154^{* *}$ & $0.00206^{* * *}$ & 0.000800 & 0.000771 & 0.00126 \\
\hline & $(0.000755)$ & $(0.000780)$ & $(0.000777)$ & $(0.000738)$ & (0.000720) & (0.000772) \\
\hline \multirow[t]{2}{*}{ POP } & $0.00494^{* * *}$ & $0.00622^{* * * *}$ & $0.00501 * * *$ & $0.00434^{* *}$ & $0.00529 * * *$ & $0.00468^{* *}$ \\
\hline & $(0.00180)$ & $(0.00194)$ & $(0.00193)$ & $(0.00181)$ & $(0.00176)$ & $(0.00182)$ \\
\hline \multirow[t]{2}{*}{$\mathrm{HC}$} & $0.00654^{* *}$ & 0.00541 * & $0.00656^{* *}$ & 0.00213 & 0.00490 * & $0.00575^{* *}$ \\
\hline & $(0.00275)$ & $(0.00283)$ & $(0.00275)$ & $(0.00251)$ & $(0.00257)$ & $(0.00288)$ \\
\hline \multirow[t]{2}{*}{ FDI } & $-6.71 \times 10^{-6}$ & $7.20 \times 10^{-5}$ & $5.03 \times 10^{-5}$ & $2.02 \times 10^{-5}$ & $2.85 \times 10^{-5}$ & $7.92 \times 10^{-5}$ \\
\hline & $\left(6.63 \times 10^{-5}\right)$ & $\left(7.23 \times 10^{-5}\right)$ & $\left(6.90 \times 10^{-5}\right)$ & $\left(6.50 \times 10^{-5}\right)$ & $\left(6.67 \times 10^{-5}\right)$ & $\left(6.75 \times 10^{-5}\right)$ \\
\hline \multirow[t]{2}{*}{ TRADE } & $0.000402^{* *}$ & $0.000355^{* *}$ & $0.000389^{* *}$ & 0.000330 * & $0.000556^{* * *}$ & $0.000391 * *$ \\
\hline & $(0.000177)$ & $(0.000178)$ & $(0.000178)$ & $(0.000178)$ & $(0.000168)$ & $(0.000185)$ \\
\hline \multirow[t]{2}{*}{ LOCAL } & $0.417 *$ & $0.430 * *$ & $0.485^{* *}$ & $0.488^{* *}$ & 0.410 * & $0.439 *$ \\
\hline & $(0.226)$ & $(0.215)$ & $(0.213)$ & $(0.224)$ & $(0.219)$ & $(0.230)$ \\
\hline \multirow[t]{2}{*}{ Constant } & -1.353 & -1.024 & -1.300 & $-1.875 *$ & -1.099 & -1.473 \\
\hline & $(1.072)$ & $(0.978)$ & $(0.975)$ & $(1.124)$ & $(1.069)$ & $(1.101)$ \\
\hline Country FE & YES & YES & YES & YES & YES & YES \\
\hline Industry FE & YES & YES & YES & YES & YES & YES \\
\hline Year FE & YES & YES & YES & YES & YES & YES \\
\hline Observations & 3835 & 3835 & 3835 & 3835 & 3835 & 3835 \\
\hline R-squared & 0.092 & 0.094 & 0.092 & 0.100 & 0.103 & 0.089 \\
\hline
\end{tabular}

Note: ${ }^{* * *},{ }^{* *}$, and ${ }^{*}$ represent significance at the $1 \%, 5 \%$, and $10 \%$ levels, respectively. The values in parentheses underneath the estimated coefficients are the corresponding robust standard errors.

\section{Conclusions and Policy Implications}

Recent decades have witnessed not only an increase in the scale of global migration but also the diversity of immigrants in destination countries. At the same time, owing to rapid globalization, international trade is increasingly being organized within global value chains (GVCs). Hence, the production position of participating countries within GVCs has become an important policy issue. A higher position within GVCs involves the production of higher value-added goods or stages of production of the relevant goods. How can nations improve their production position within GVCs? While linking immigrant diversity with production position within GVCs, we paid special attention to the role of the institutional quality in destination countries.

We argued that immigrant diversity generates two opposite effects on GVC positions of destination countries. These effects are the capability pool effect and social conflict effect. The former has a positive impact on GVCs position, while the latter has a negative impact on GVC positions. Using a sample that covered 19 manufacturing sectors in 18 OECD countries over the 2000-2014 period and employing the fixed effects estimation technique, we found that the overall effect of immigrant diversity on the GVC position of destination countries was positive. This implies that the capability pool effect of immigrant diversity on the GVC position more than offsets the negative social conflict effect. Further analysis showed that the institutional quality of destination countries affects the impact of immigrant diversity on production positions within GVCs. Our empirical analysis revealed that the higher the institutional quality of destination countries, the capability effect was more likely to be higher than the social conflict effect. Hence, in the destination countries with higher institutional quality, the effect of immigrant diversity on the GVC position is positive. By contrast, in destination countries with low institutional quality, the effect of immigrant diversity on the GVC position is negative. 
Further analysis showed that the moderating effect of the institutional quality on the relationship between immigrant diversity and the GVC position of destination countries varied across education levels of immigrants. Specifically, the institutional quality had a stronger moderating effect on the immigrant diversity-GVC position nexus for immigrants with lower education levels. Disaggregated analysis based on six dimensions of the institutional quality showed that only three dimensions of the institutional quality (i.e., government efficiency, political stability, and regulatory quality) exerted a statistically significant effect on the impact of immigrant diversity on the GVC position of destination countries.

The results presented in this paper have important policy implications for developing countries. First, to promote the production and trade position within GVCs, developing countries should not only attract more overseas talent but also pay more attention to their diversity. Second, to take full advantage of the positive effect of immigrant diversity on the GVC position, developing countries need to provide a good institutional environment, in particular, improving the government efficiency, political stability, and regulatory quality.

Author Contributions: Conceptualization, S.A. and Y.Z.; methodology, S.A.; software, Y.Z.; validation, S.A. and Y.Z.; formal analysis, S.A.; investigation, Y.Z.; resources, S.A.; data curation, Y.Z.; writing-original draft preparation, S.A.; writing-review and editing, S.A.; visualization, Y.Z.; supervision, S.A.; project administration, S.A.; funding acquisition, S.A. All authors have read and agreed to the published version of the manuscript.

Funding: The authors acknowledge financial support from the National Social Sciences Fund of China (No. 19BJY192), the Fundamental Research Funds for the Central Universities of China (No. 19JNLH06) and the Funds of Soft Sciences of Guangdong, China (No. 2019A101002023). The APC was funded by Sajid Anwar.

Institutional Review Board Statement: Not applicable.

Informed Consent Statement: Not applicable.

Data Availability Statement: The Global Value Chain Database can be obtained by logging in http:/ /rigvc.uibe.edu.cn/sjzlk/sjk/9a08cef3995842fa88b7cebd1aec5aab.htm (accessed on 4 January 2022). The Institute for Employment Research bilateral migration database can be obtained by logging in https: / / www.iab.de/en/ueberblick.aspx (accessed on 4 January 2022), and the World Bank database can be obtained by logging in https:/ / data.worldbank.org (accessed on 4 January 2022).

Acknowledgments: The authors are extremely grateful to two anonymous reviewers and an associate editor for very helpful comments and suggestions. However, all remaining errors and/or imperfections are the sole responsibility of the authors.

Conflicts of Interest: The authors declare no conflict of interest.

\section{References}

1. Parrotta, P.; Pozzoli, D.; Pytlikova, M. Labor diversity and firm productivity. Eur. Econ. Rev. 2014, 66, 144-179. [CrossRef]

2. Trax, M.; Brunow, S.; Suedekum, J. Cultural diversity and plant-level productivity. Reg. Sci. Urban Econ. 2015, 53, 85-96. [CrossRef]

3. Ottaviano, G.I.; Peri, G. The economic value of cultural diversity: Evidence from US cities. J. Econ. Geogr. 2006, 6, 9-44. [CrossRef]

4. Ozgen, C.; Nijkamp, P.; Poot, J. The impact of cultural diversity on firm innovation: Evidence from Dutch micro-data. IZA J. Migr. 2013, 2, 1-24. [CrossRef]

5. Alesina, A.; Ferrara, E.L. Ethnic diversity and economic performance. J. Econ. Lit. 2005, 43, 762-800. [CrossRef]

6. Alesina, A.; Harnoss, J.; Rapoport, H. Birthplace diversity and economic prosperity. J. Econ. Growth 2016, 21, 101-138. [CrossRef]

7. Docquier, F.; Turati, R.; Valette, J.; Vasilakis, C. Birthplace diversity and economic growth: Evidence from the US states in the Post-World War II period. J. Econ. Geogr. 2020, 20, 321-354.

8. Bahar, D.; Rapoport, H.; Turati, R. Birthplace diversity and economic complexity: Cross-country evidence. Res. Policy 2020, in press. [CrossRef]

9. Baldwin, J.; Yan, B. Global value chains and the productivity of Canadian manufacturing firms. Stat. Can.=Stat. Can. 2014, 11F0027M, 90.

10. Angelidis, G.; Ioannidis, E.; Makris, G.; Antoniou, I.; Varsakelis, N. Competitive Conditions in Global Value Chain Networks: An Assessment Using Entropy and Network Analysis. Entropy 2020, 22, 1068. [CrossRef] 
11. Alves, L.G.A.; Mangioni, G.; Rodrigues, F.A.; Panzarasa, P.; Moreno, Y. Unfolding the complexity of the global value chain: Strength and entropy in the single-layer, multiplex, and multi-layer international trade networks. Entropy 2018, 20,909. [CrossRef] [PubMed]

12. Angelidis, G.; Bratsas, C.; Makris, G.; Ioannidis, E.; Varsakelis, N.C.; Antoniou, I.E. Global Value Chains of COVID-19 Materials: A Weighted Directed Network Analysis. Mathematics 2021, 9, 3202. [CrossRef]

13. Hagemejer, J.; Ghodsi, M. Up or down the value chain? A comparative analysis of the GVC position of the economies of the new EU member states. Cent. Eur. Econ. J. 2017, 1, 19-36. [CrossRef]

14. Szymczak, S.; Wolszczak-Derlacz, J.; Parteka, A. Position in global value chains: The impact on wages in Central and Eastern European Countries. No. 1/2019 (53). GUT FME Work. Pap. Ser. A 2019, 1, 53.

15. Sun, C.; Li, Z.; Ma, T.; He, R. Carbon efficiency and international specialization position: Evidence from global value chain position index of manufacture. Energy Policy 2019, 128, 235-242. [CrossRef]

16. Hu, D.; Jiao, J.; Tang, Y.; Han, X.; Sun, H. The effect of global value chain position on green technology innovation efficiency: From the perspective of environmental regulation. Ecol. Indic. 2021, 121, 107195. [CrossRef]

17. Bove, V.; Elia, L. Migration, diversity, and economic growth. World Dev. 2017, 89, 227-239. [CrossRef]

18. Schmader, T.; Johns, M.; Forbes, C. An integrated process model of stereotype threat effects on performance. Psychol. Rev. 2008, 115, 336. [CrossRef]

19. Le, H.T.; Hoang, D.P.; Doan, T.N.; Pham, C.H.; To, T.T. Global economic sanctions, global value chains and institutional quality: Empirical evidence from cross-country data. J. Int. Trade Econ. Dev. 2021, in press. [CrossRef]

20. Park, S.; Park, I. The value-added creation effect of industry position in global value chains: Implications for Asia-Pacific economies. Asian-Pac. Econ. Lit. 2021, 35, 95-122. [CrossRef]

21. Gereffi, G.; Humphrey, J.; Sturgeon, T. The governance of global value chains. Rev. Int. Political Econ. 2005, 12, 78-104. [CrossRef]

22. Humphrey, J.; Schmitz, H. Governance in global value chains. IDS Bull. 2001, 32, 19-29. [CrossRef]

23. Gibbon, P.; Bair, J.; Ponte, S. Governing global value chains: An introduction. Econ. Soc. 2008, 37, 315-338. [CrossRef]

24. Nadvi, K. Global standards, global governance and the organization of global value chains. J. Econ. Geogr. 2008, 8, 323-343. [CrossRef]

25. Timmer, M.P.; Erumban, A.A.; Los, B.; Stehrer, R.; De Vries, G.J. Slicing up global value chains. J. Econ. Perspect. 2014, 28 , 99-118. [CrossRef]

26. Horwitz, S.K.; Horwitz, I.B. The effects of team diversity on team outcomes: A meta-analytic review of team demography. $J$. Manag. 2007, 33, 987-1015. [CrossRef]

27. Nooteboom, B. Learning and Innovation in Organizations and Economies; OUP Oxford: New York, NY, USA, 2000.

28. Hong, L.; Page, S.E. Groups of diverse problem solvers can outperform groups of high-ability problem solvers. Proc. Natl. Acad. Sci. USA 2004, 101, 16385-16389. [CrossRef] [PubMed]

29. Hamilton, B.H.; Nickerson, J.A.; Owan, H. Team incentives and worker heterogeneity: An empirical analysis of the impact of teams on productivity and participation. J. Political Econ. 2003, 111, 465-497. [CrossRef]

30. Shachaf, P. Cultural diversity and information and communication technology impacts on global virtual teams: An exploratory study. Inf. Manag. 2008, 45, 131-142. [CrossRef]

31. Kemeny, T.; Cooke, A. Urban immigrant diversity and inclusive institutions. Econ. Geogr. 2017, 93, 267-291. [CrossRef]

32. Hausmann, R.; Hidalgo, C.A. The network structure of economic output. J. Econ. Growth 2011, 16, 309-342. [CrossRef]

33. Antràs, P.; Staiger, R.W. Offshoring and the role of trade agreements. Am. Econ. Rev. 2012, 102, 3140-3183. [CrossRef]

34. Feldman, M.P.; Audretsch, D.B. Innovation in cities: Science-based diversity, specialisation and localised competition. Eur. Econ. Rev. 1999, 43, 409-429. [CrossRef]

35. Duranton, G.; Puga, D. Nursery cities: Urban diversity, process innovation, and the life cycle of products. Am. Econ. Rev. 2001, 91, 1454-1477. [CrossRef]

36. Florida, R. The economic geography of talent. Ann. Assoc. Am. Geogr. 2002, 92, 743-755. [CrossRef]

37. Ellison, G.; Glaeser, E.L.; Kerr, W.R. What causes industry agglomeration? Evidence from coagglomeration patterns. Am. Econ. Rev. 2010, 100, 1195-1213. [CrossRef]

38. Ozgen, C.; Nijkamp, P.; Poot, J. Immigration and innovation in European regions. In Migration Impact Assessment; Edward Elgar Publishing: Cheltenham, UK, 2012.

39. Abrams, D.; Hogg, M.A. (Eds.) Social Identity Theory: Constructive and Critical Advances; Springer Publishing: Berlin/Heidelberg, Germany, 1990.

40. Chatman, J.A.; Flynn, F.J. The influence of demographic heterogeneity on the emergence and consequences of cooperative norms in work teams. Acad. Manag. J. 2001, 44, 956-974.

41. Harrison, D.A.; Klein, K.J. What's the difference? Diversity constructs as separation, variety, or disparity in organisations. Acad. Manag. Rev. 2007, 32, 1199-1228. [CrossRef]

42. Van Knippenberg, D.; Schippers, M.C. Work group diversity. Annu. Rev. Psychol. 2007, 58, 515-541. [CrossRef]

43. Krifa-Schneider, H.; Matei, I. Business climate, political risk and FDI in developing countries: Evidence from panel data. Int. J. Econ. Financ. 2010, 2, 54-65. [CrossRef]

44. Wang, J.; Li, Z.; Sun, X. Empirical Analysis on the Influence of Business Environment on Foreign Direct Investment Inflow Based on the Panel Data on 26 Countries. Int. J. Sustain. Dev. Plan. 2020, 15, 1223-1230. [CrossRef] 
45. Nunn, N. Relationship-specificity, incomplete contracts, and the pattern of trade. Q. J. Econ. 2007, 122, 569-600. [CrossRef]

46. Levchenko, A.A. Institutional quality and international trade. Rev. Econ. Stud. 2007, 74, 791-819. [CrossRef]

47. Dollar, D.; Kidder, M. Institutional quality and participation in global value chains. In Global Value Chain Development Report: Measuring and Analyzing the Impact of GVCs on Economic Development; UIBE: Beijing, China, 2017; pp. 161-173.

48. Wang, Z.; Wei, S.J.; Yu, X.; Zhu, K. Measures of Participation in Global Value Chains and Global Business Cycles; No. w23222; National Bureau of Economic Research: Cambridge, MA, USA, 2017.

49. Gutiérrez, J.B.; Crespo, E.R. The Role of Institutional Quality on Participation in Global Value Chains. Cuad. Econ. ICE 2020, 100, 35-57.

50. Kaufmann, D.; Kraay, A.; Mastruzzi, M. The Worldwide Governance Indicators: Methodology and Analytical Issues1. Hague J. Rule Law 2011, 3, 220-246. [CrossRef]

51. IAB. Institute for Employment Research. 2021. Available online: https:/ /www.iab.de/en/ueberblick.aspx (accessed on 27 April 2021).

52. The World Bank. The World Bank Database. 2021. Available online: https:/ / data.worldbank.org/ (accessed on 27 April 2021).

53. Grogger, J.; Hanson, G.H. Income Maximization and the Selection and Sorting of International Migrants. J. Dev. Econ. 2011, 95, 42-57. [CrossRef]

54. Beine, M.; Docquier, F.; Schiff, M. International migration, transfer of norms and home country fertility. Can. J. Econ. 2013, 46, 1406-1430. [CrossRef]

55. Ortega, F.; Peri, G. Openness and income: The roles of trade and migration. J. Int. Econ. 2014, 92, 231-251. [CrossRef]

56. Esipova, N.; Ray, J.; Pugliese, A. Gallup World Poll: The Many Faces of Global Migration; United Nations: Geneva, Switzerland, 2011.

57. Koopman, R.; Wang, Z.; Wei, S.J. Tracing value-added and double counting in gross exports. Am. Econ. Rev. 2014, 104, 459-494. [CrossRef] 